\title{
Avifaunal Diversity and Conservation Status in Bastar District of Chhattisgarh, India : An Update
}

\section{Sushil Kumar Dutta}

Department of Zoology, Govt. PG College, Jagdalpur, Chhattisgarh, India

Study Area: District Bastar, Chhattisgarh, India Coordinates: $80.5^{\circ}-82.1^{\circ} \mathrm{E} ; 18.4^{\circ}-19.9^{\circ} \mathrm{N}$

Key words: Migratory, Resident, Rare, Uncommon, First Report from Central India (FRCI).

\section{Abstract}

Currently, the Bastar Plateau is divided into 7 districts. The present avifaunal survey has been focused specifically on Bastar district. This paper describes the detail of sightings and adds 50 newly recorded species to the avifaunal diversity of Bastar district. From the total 5o bird species; 14 bird species were re-encountered as recorded earlier from Bastar plateau. Interestingly, out of 50 new records; 06 species are the first record to Central India. The current 50 new avifauna species adds to the previous record and updates the avifauna diversity of the Bastar district to 319 species.

$\mathrm{Km}^{2}$. Tributaries of Indravati River and Sabri River drains through the region and meets the river Godavari. The Indravati River enters the district from the east; traversing through the middle trailing towards west. Biogeographically, the plateau is included in the Eastern Highlands (6C) province of the Deccan Peninsula of India (Rodgers et al., 2002). Now, the whole plateau is divided into 7 districts; viz., Uttar Bastar - Kanker, Kondagaon, Narayanpur and Dakshin Bastar - Dantewada, Bijapur, Bastar and Sukma. The present field survey on avifaunal diversity was conducted specifically in the proper Bastar district of the Chhattisgarh.

The present survey area (Bastar District) covers an area of $4,029.98 \mathrm{Km}^{2}$; just over $1 / 9$ th of Dandkaranya Plateau or Bastar Plateau. A portion of east and majority of the north of the district is a plain area with sporadic forests, dominated by agriculture fields and water bodies. Southeast of the district is a Protected Area designated as Kanger Valley National Park (KNVP), which is well known for its relevance to biodiversity, varied habitats, limestone caves, and waterfalls. Fringing to the east of the KVNP is the Machkot Forest Range (MFR), a Reserve Forest which is equally rich in biodiversity. The maximum part of the surveyed area lies in the Deccan-trap Plateau with altitude ranging from $200 \mathrm{~m}$ to $1200 \mathrm{~m}$ above the mean sea level (MSL).

Survey and Data Collection: a systematic long-term intensive survey in any targeted area results in good conf irmatory sightings, recording of possibly more new species and re-encounters of species. Our surveys were carried out on the above principles. New areas of Bastar 
district were surveyed spanning through different seasons of the years. Identification was done following Ali \& Ripley (1968-1974), Grimmett et al. (2011) and Kazmierczak (2012). All the standardized common names have been based on Praveen et al. (2016). Research work on avifaunal diversity was undertaken from 01/01/2015 to 29/10/2017; which is an update of the Bastar district as well as Chhattisgarh Avifaunal diversity.

\section{Results \& discussion:}

The state of Chhattisgarh was carved out of Madhya Pradesh on 1st of November 200o. Most of the avifaunal inventory of Central India, prior to the year 2000 were inclusive of both states or of some protected areas. Majumder (1984) published a list of 97 bird species from Bastar district (formed in 1948 by the union of two princely states of Bastar and Kanker); Saha (1995) reported 92 species of birds from Indravati Tiger Reserve; Chandra \& Singh (2004) reviewed the avifauna of Madhya Pradesh and Chhattisgarh listing a total of 517 species/subspecies among which 197 species and subspecies were reported from Chhattisgarh. An avifaunal survey of the Protected Areas (PAs) of Chhattisgarh reported 131 species of birds in Kanger Valley National Park and 123 species in Guru Ghasidas National Park (Chakraborty, 2008). Further, Pande et al., 2012 described 404 avian species for the entire state of Chhattisgarh in a pictorial guidebook. Chandra et al., 2015 updated the checklist of avifaunal diversity of Bastar plateau to a total of 304 species belonging to 194 genera under 63 families with the new addition of 89 species of which 5 species, viz. Gallicrex cinerea, Vanellus cinereus, Cypsiurus balasiensis, Anthreptes singalensis and Oriolus chinensis were the first record from the Central India (undivided Madhya Pradesh and Chhattisgarh). From this 266 bird species were recorded specifically in recent Bastar district inclusive of above 5 first records to Central India. Dutta (2016a) reported a single species note on Spot-billed Pelican Pelecanus philippensis which had been mentioned in the given checklist. Eralier, three rare birds from the district viz., Rufous-bellied Eagle Hieraaetus kienerii Dutta (2015); trans-equatorial migrant Amur falcon, Falco amurensis Dutta (2016b) and Ruddy-breasted Crake Porzana fusca Dutta, 2017 had already been reported. Reports on these new sightings add up to the avifaunal diversity from Bastar district to 269 species. Table -1, details about 50 species of avifauna belongs to 23 families of o9 orders; highlighting the habitat type, local status and abundance as following Migratory status: RS-Resident; WM-Winter Migrant; SM Summer Migrant; PM-Passage Migrant. Abundance and frequency of sighting: R-Rare (1-3 encounter); UCUncommon (4-6 encounter); C-Common (7-10 encounter); A-Abundant (>10 encounter). The given table highlighting the detail of sightings and adds 50 newly recorded species to the avifaunal diversity of Bastar

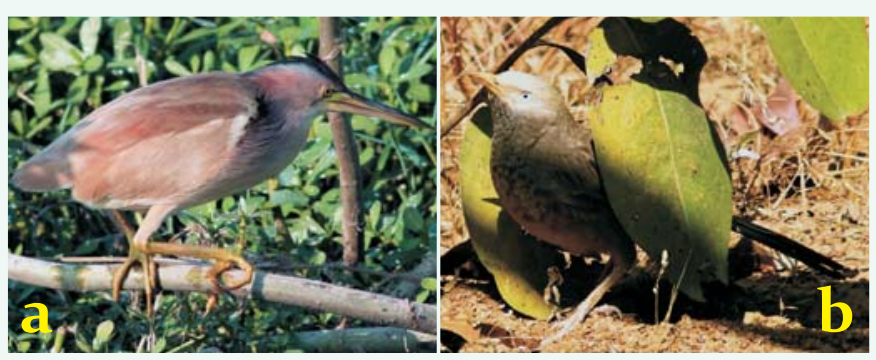

Figure-1: (a) Yellow Bittern Ixobrychus sinensis; (b) Yellowbilled Babbler Turdoides affinis

district. From the total 50 bird species; 14 bird species were re-encounters which were earlier records of Bastar plateau. Interestingly, out of 50 new records, 06 species are the first record from Central India. The current 50 new avifauna species adds to our previous records Chandra et al. (2015) and the updates avifauna diversity of the Bastar district to a figure of 319 species. All the 50 species recorded from Bastar district indicates the habitat needs of these birds. Some 30 species were sighted in and around water bodies or adjacent areas while 20 species were found in the moist thickets of Reserve Forest or Protected Areas with springs, streams or nalas (drainage). Conservation priorities for birds in Bastar district need to conserve and protect these habitats or ecosystems. As per IUCN category, three species i.e., Black-tailed Godwit Limosa limosa, Eurasian Curlew Numenius arquata and Pallid Harrier Circus macrourus come under 'Near Threatened' category and only one i.e., Indian Spotted Eagle Clanga hastata comes under 'Vulnerable' category, while rest 46 species are under Least Concern since 2016. Generally, the IUCN status of the species considers global population but the result of the present abundance of the birds in Bastar district is not satisfactory as group size of most sightings ranged from 1 to 6 in number except the Yellow Bittern were more than 10 in numbers.

From the present record, atleast two species need special attention; i) Yellow Bittern Ixobrychus sinensis (Fig.-1a) is the first record from Central India and sighted throughout the year around the Dalpat Sagar, a lake in the mid of Jagdalpur city. This species is in good numbers in the adjacent paddy fields. The juveniles of the species were sighted during the month of May and June in 2016 and 2017; ii) Yellow-billed Babbler Turdoides affinis (Fig.-1b) is also the first record from Central India. Three separate sightings were observed in Bakawand area. It is an uncommon species, not specified in range maps of Kazmierczak (1998) and Grimmett et al. (2011). Prior to this report, the species was reported from southern states of India and Sri Lanka. Earlier, this species was considered as a resident of Peninsular India and Sri Lanka (Grimmett et al., 2011). The species possibly has made its area of extension into this region which might be the bird's farthest northern distribution in Central India reported till date. 


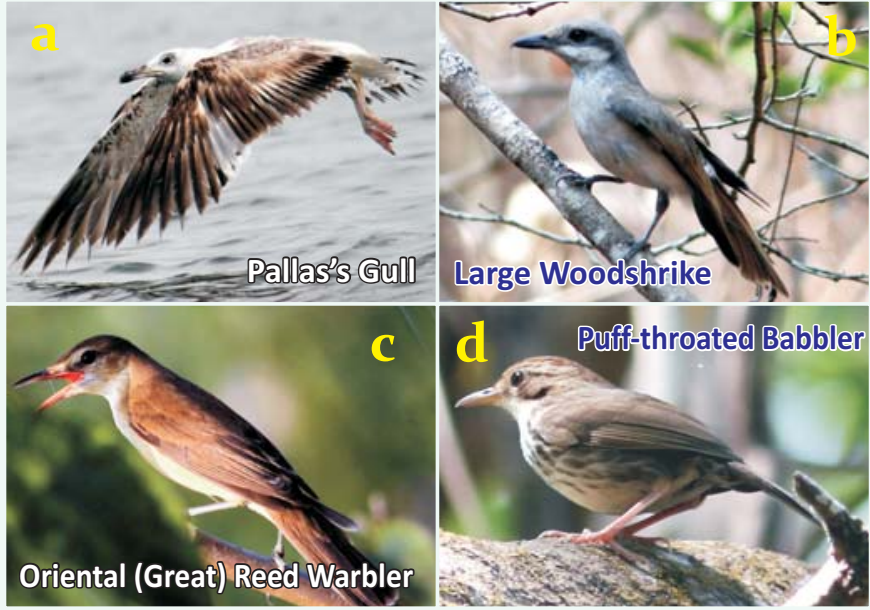

Figure-2: Birds seen for the first time from Central india. a) Ichthyaetus ichthyaetus; b) Tephrodornis virgatus; c) Acrocephalus orientalis; d) Pellorneum ruficeps

Sites like Dalpat Sagar, Rajnagar tank, Bakavand area, Bajavand tank, Kanger Valley National Park and Machkot Forest have been identif ied as hotspot zones for the birds which require immediate protection and conservation plan. Many of these sites are abode to numerous migratory as well as rare birds. Proper studies on population dynamics of avians in the drainage of moist forest and wetlands are highly recommended.

\section{Conclusion:}

The study indicates the potential areas for bird conservation within the district of Bastar. It's rich and unique in its faunal composition sharing the characteristics of both northern and southern part of the country and possibly a break-journey stopover for many migratory birds on their regular flyway. The present avifaunal diversity accounts for 319 species and may be considered as the baseline information for further studies related to the avifaunal conservation. Birds are often considered as potential indicators of environment and sighting of these new birds in the region enriches our understanding of various habitats and thus indicates proper planning and conservation action are needed to preserve them and their arrival in future.

\section{Acknowledgements:}

Dr. Muntaz Khan, Prof V.C. Awasthi, Dr.P.R.S.Nagi, Ankur Shekdar and R. P. Gupta for helping in identification of birds, preparation of the manuscript and for thorough help.

\section{References:}

Ali, S. \& Ripley, S.D. (1968-74): Handbook of the Birds of India \& Pakistan (10 Vols.). Pub. by: Oxford University Press.

Chakraborty, R. (2008): Aves. In: ed.- Director, Vertebrate Fauna of Kanger ghati, Guru Ghasidas and Sanjay National Park (Madhya Pradesh and Chhattisgarh). Conservation Area Series, Zoological Survey of India, 36: 69-180.

Table-1: List of the birds species recorded from Bastar District of Chhattisgarh (an update of 2015-2017)

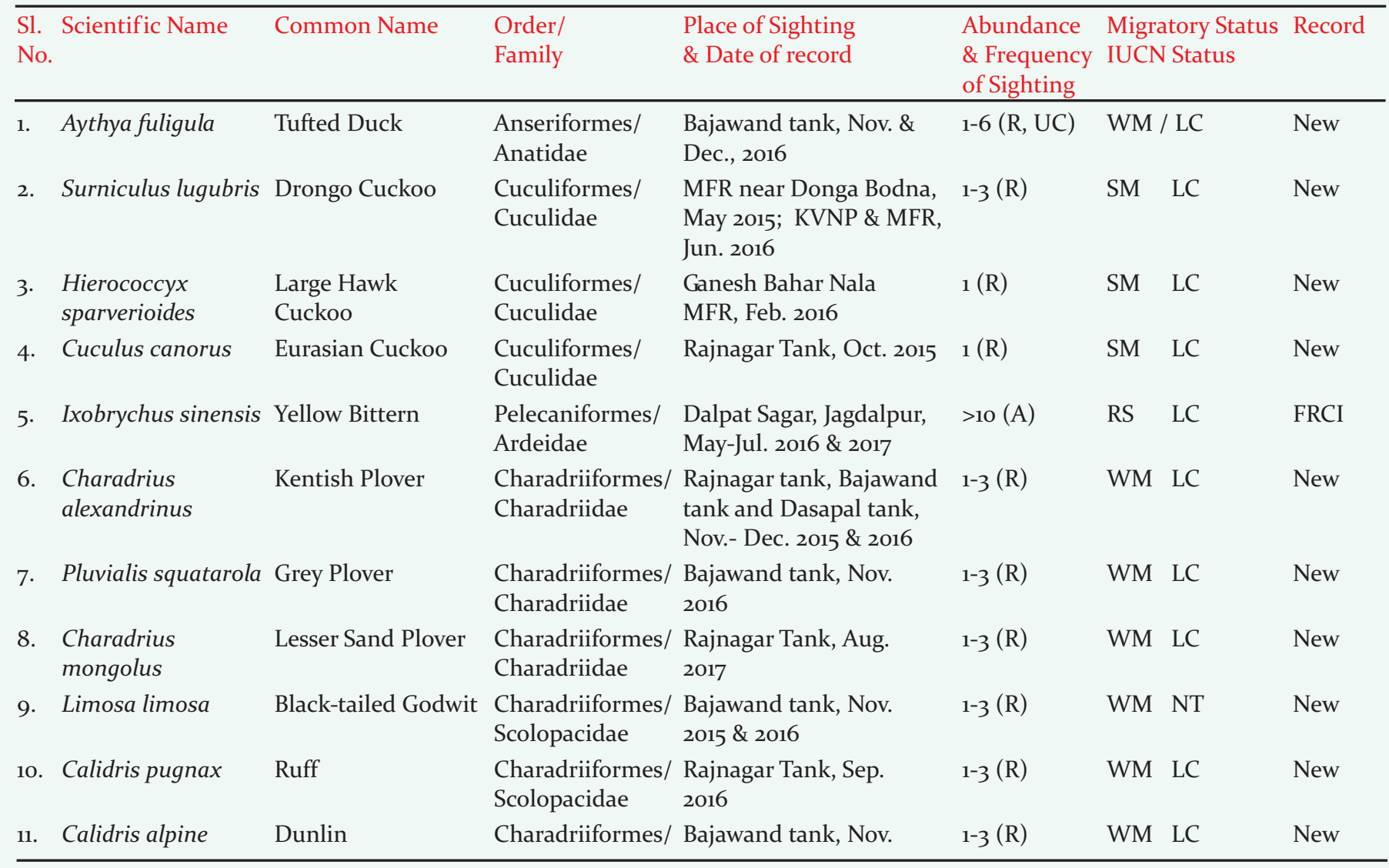


Ambient Science, 2017: Vol. 04(2); 31-35

DOI:10.21276/ambi.2017.04.2.ra06

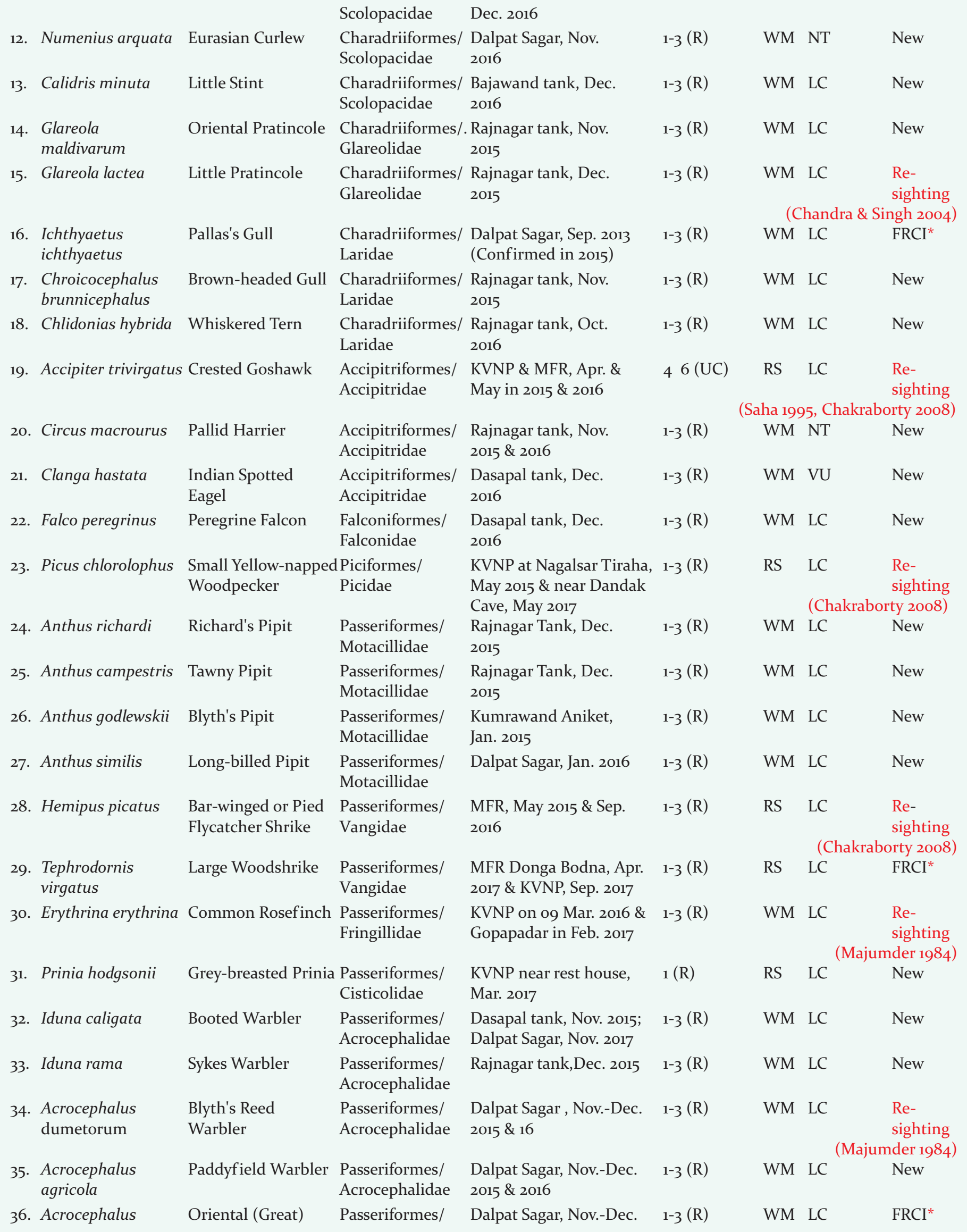


orientalis
37. Acrocephalus
stentoreus

Reed Warbler

Clamorous Reed

Warbler (Indian

Great Reed Warbler)

38. Seicercus occipitalis Western Crowned Warbler

39. Mixornis gularis

Pin-striped Tit Babbler or Yellowbreasted Babbler

40. Pellorneum ruficeps Puff-throated Babbler

41. Alcippe poioicephala Brown Cheeked Fulvetta or Quaker

42. Turdoides affinis

Yellow-billed Babbler

43. Monticola cinclorhyncha

Blue-capped

Rock-thrush

44. Oenanthe deserti

Desert Wheatear

45. Saxicola maurus

Common (Siberian)

stonechat

46. Turdus unicolor

Tickell's Thrush

47. Lonchura malacca

Black-headed Munia

48. Ninox scutulata

Brown Hawk Owl

49. Strix leptogrammica Brown Wood Owl

50. Otus bakkamoena

Collared Scops Ow
Acrocephalidae

Passeriformes/

Acrocephalidae

Passeriformes/

Phylloscopidae

Passeriformes/

Timaliidae

Passeriformes/

Pellorneidae

Passeriformes/

Leiothrichidae

Passeriformes/

Leiothrichidae

Passeriformes/

Muscicapidae

Passeriformes/ Muscicapidae

Passeriformes/

Muscicapidae

Passeriformes/

Turdidae

Passeriformes/

Estrildidae

Strigiformes/

Strigidae

Strigiformes

Strigidae

Strigiformes/

Strigidae
2015 \& 2016

Dalpat Sagar, dec.-Jan. $\quad$ 1-3 (R)

WM LC

New

2015 \& 2016

MFR, Mar.-Apr. 2016

$$
1-3(R)
$$

WM LC

New

KVNP and MFR, Apr.-

May, 2016 \& 2017

$$
\text { 4-6 (UC) }
$$

RS LC

Re-

MFR, Feb., Apr. \& May 2016

MFR, Feb. \& Apr. 2016

\& 2017

Bakawand area, Dec. \&

Apr. 2016 \& 2017

KVNP, Mar. \& Apr.

2015 \& 2016

Rajnagar tank, Dec. 2016 1-3 (R)

(Majumder 1984, Chakraborty 2008)

4-6 (UC) RS LC FRCI* $^{*}$

4-6 (UC) RS LC Re-

Tit Babbler

sighting

1-3 (R) RS LC FRCI*

1-3 (R) WM LC Re-

sighting

(Majumder 1984, Chakraborty 2008)

Rajnagar tank, Dec. \& 1-3 (R) WM LC New

Jan. 2015 \& 2016

MFR, Feb. 2016

$1-3(\mathrm{R})$

WM LC

Resighting

(Chakraborty 2008)

Most water bodies, Nov. - 4-6 (UC) RS LC Re-

Apr. 2015 - 2017

MFR , May 2015 \&

KVNP, Apr. 2017

$1-3(\mathrm{R})$

KVNP, Mar. 2015

$1-3(\mathrm{R})$

(Majumder 1984)

RS LC Re-

sighting

(Saha 1995)

Re-

sighting

MFR near Navin Naka 1-3 (R)

(Majumder 1984)

Kurandi, Apr. 2016.
Re-

sighting

(Majumder 1984, Saha 1995)

*Refer- figure-2

Chandra, K. \& Singh, R.K. (2004): Avifauna of Madhya Pradesh and Chhattisgarh. Zoo's Print, 19(7):1534-1539.

Chandra, K., Dutta S.K., Gupta R.P., \& Raha, A. (2015): Diversity and conservational status of avifauna in Bastar plateau of Chhattisgarh, India. Ambient Sci., 02(1):31-43.

Dutta, S.K. (2015): First report of Rufous bellied Eagle, Hieraaetus kienerii from Chhattisgarh, India. Biolife, 3(2):561-563.

Dutta, S.K., (2016a): Sighting of Spot-billed Pelican Pelecanus philippensis in Bastar plateau, Chhattisgarh, India. Ind. Birds, 11(4): 100 .

Dutta, S.K. (2016b): First report of Amur Falcon, Falco amurensis from Chhattisgarh, India. Biolife, 4(3):437-440.

Dutta, S.K. (2017): First Report of Ruddy-breasted Crake Porzana fusca (Linnaeus, 1766) from Chhattisgarh. Int. J. Curr. Microbiol. App. Sci., 6(1):472-476.

Grimmett, R., Inskipp, C. \& Inskipp, T. (2011): Birds of the Indian subcontinent. Pub. by: Oxford University Press. 384 pp.
Kazmierczak, K., (200o): A field guide to the birds of India, Sri Lanka, Nepal, Bhutan, Bangladesh, and the Maldives. Pub. by: Om Book Service, New Delhi. 352 pp.

Majumder, N. (1984): On a collection of birds from Bastar District, M.P. Rec. Zool. Surv. India. Occ. paper 54:59.

Pande, S., Deshpande, P., Sant, N., Chandra, K. \& Boaz, A. (2012): Birds of Chhattisgarh. Pub. by: Ela Foundation \& Chhattisgarh Forest department. xviii+226p.

Praveen, J., Jayapal R., \& Pittie, A. (2016): A checklist of the birds of India, Ind. Birds, 11(5\&6): 113-172.

Rodgers,W.A., Panwar, H.S. \& Mathur, V.B. (2002): Wildlife and protected areas network in India. A review (Executive Summary). Pub. by: Wildlife Institute of India, Dehradun.

Saha, S.S. (1995): Aves. In ed.- Director, Fauna of Indravati Tiger Reserve. Conservation Area Series, Zoological Survey of India. 6; 85-91. 